\title{
Doctors in the Zoo: Connecting Human and Animal Health in British Zoological Gardens, c.1828-1890
}

\section{Abigail Woods}

In 1865, the Royal Zoological Society of Ireland (RZSI) announced the death of a three-year-old male Indian rhino in its Dublin Zoological Gardens. The event was a considerable blow to the society, which had paid $£ 160$ for the unusual creature in the hope of inspiring scientific and public interest in the zoo. However, on arrival from Calcutta just eight months previously, the rhino was already sickly and suffering from fits. It was attended by three medical members of the RZSI, including the secretary, Reverend Professor Samuel Haughton, of Trinity College Dublin (TCD), who recommended the administration of three pints of boiled rice with bran, and a gallon of milk with some tonic mixed in. However, the fits continued. Haughton elected to increase the dose of tonic and remove cabbage from the diet. This brought about a temporary improvement, but in April 1865 the animal was found in pain with a prolapsed rectum. Haughton, two other doctors and two vets were summoned. They administered castor oil, opium, aromatic spirits of ammonia and turpentine, but to no avail. ${ }^{1}$

After its death the rhino continued to attract attention. The Royal Dublin Society offered $£ 15$ for the body in the hope of adding to its collection of comparative anatomy specimens. It was outbid by Haughton, who habitually dissected animals that died in the zoo. ${ }^{2}$ His post-mortem

\footnotetext{
${ }^{1}$ de Courcy (2010). See also de Courcy (2009).

${ }^{2}$ de Courcy (2010), Proceedings of the Royal Zoological Society of Ireland (1863-1864) p. 13.
}

(C) The Author(s) 2018

A. Woods et al., Animals and the Shaping of Modern Medicine,

Medicine and Biomedical Sciences in Modern History,

https://doi.org/10.1007/978-3-319-64337-3_2 
examination of the rhino's pathology and anatomy was attended by anatomists, medical men and the queen's veterinary surgeon for Ireland, with assistance provided by medical students and the demonstrator in anatomy at the Royal College of Surgeons, Ireland. By then, the rhino had begun to decompose and the stench from its body was almost intolerable, causing several of the attendants to suffer typhoid diarrhoea. Examination revealed that its rectum had prolapsed and ruptured, and its stomach was distended almost to bursting with fermenting Indian corn. This had exerted pressure on the diaphragm, leading to death by suffocation. A furious Haughton instructed the council of the RZSI to institute a searching enquiry as to why the rhino had been fed corn when it was not listed on the society's formally prescribed dietary. ${ }^{3}$ Proceeding to dissect the remainder of the body, he wrote a lengthy report on the rhino's muscles, which he published alongside his pathological findings in the Proceedings of the Irish Academy. As number 16 in his series of 18 'Notes on Animal Mechanics', the report informed his 1873 volume, Principles of Animal Mechanics, which compared and contrasted the bodies of various species including humans, and argued-contrary to Darwin-for a teleological view of nature. ${ }^{4}$ What remained of the rhino was sent to a taxidermist and then displayed alongside other animals in the zoological museum of TCD. ${ }^{5}$

This vignette of the life, death and afterlife of the unfortunate Dublin rhino introduces several key themes that will be investigated further in this chapter. First, it offers a glimpse of the illness experiences of animals that were confined to nineteenth-century zoological gardens for their frequently short and sickly lives. Second, it reveals the sorts of human responses that those illnesses inspired. Sick animals were fashioned into patients, pathological specimens, victims of their environments and points of interspecies comparison, and subjected to medication and dietary modifications in life, and dissection after death. Third, it shows that these responses were led not, as one might expect, by veterinary surgeons but by medical men. Finally, it illustrates how, in stimulating such responses, sick animals were able to shape medical knowledge and practice, and how the zoo was run. Through exploring these themes in relation

\footnotetext{
${ }^{3}$ Haughton (1864-1866).

${ }^{4}$ Haughton (1864-1866, 1873), Adelman (2009).

${ }^{5}$ de Courcy (2010).
} 
to the London and Dublin Zoological Gardens (established in 1828 and 1831, respectively), with occasional references to Bristol (1835) and Manchester Belle Vue Zoological Gardens (1836), this chapter demonstrates the mutual shaping of animals, medicine and zoological gardens in the middle decades of the nineteenth century.

This period saw many zoological gardens established across Western Europe. Symbolizing colonial possession and mastery over nature, they were intended as bourgeois institutions, distinct from existing menageries. Engaging in new modes of animal display, public education and entertainment, zoos sought to advance knowledge of taxonomy, natural history, acclimatization, animal behaviour and comparative anatomy. These aspects of their histories are well documented. However, the health of their animal inhabitants is not. ${ }^{6}$

While animal historians have explored the lives and afterlives of certain zoo animals, and their contributions to human history, they have paid little sustained attention to their health. ${ }^{7}$ This is surprising given the extraordinarily high incidence of disease and death reported by mid-nineteenth-century zoos. In London, for example, mortality rates approached $33 \%$ per year, ${ }^{8}$ which suggests that ill health was fundamental to the lived experiences of its animals. This chapter aims to shed light on those experiences, and how animals were affected by human responses to them. It thereby addresses issues neglected by zoo historians, who are generally more concerned with the humans who founded, ran and visited zoological gardens than the animals that lived within them. On the occasions that these authors refer to animal health, they make retrospective, negative assessments of human responses to it. ${ }^{9}$ This chapter challenges such assessments by revealing the considerable attention

\footnotetext{
${ }^{6}$ Green-Armytage (1964), Akerberg (2001), Keeling (2001), Baratay and HardouinFugier (2002), Burkhardt (2002), de Courcy (2009), Nyhart (2009) pp. 79-124, Ito (2014).

${ }^{7}$ Ritvo (1987) pp. 205-42, Rothfels (2002), Benbow (2004), Adelman (2009), Alberti (2011), Flack (2013), Miller (2013), Flack (2014), Nance (2015).

${ }^{8}$ Murie (1866).

${ }^{9}$ For example: Akerberg (2001) pp. 186-94, Hancocks (2001) pp. 50-1, 73-6, Baratay and Hardouin-Fugier (2002) pp. 131-9, Burt (2002), Cowie (2014) pp. 94-8. Many of these authors rely on Chalmers Mitchell (1929), who as secretary of the Zoological Society of London, 1903-1935, claimed to have taken the first real steps to improve zoo animal health.
} 
that diseased animals attracted during this period, and the many ways in which medical men attempted to understand and promote their health.

The health of zoo animals is equally overlooked by medical historians. As noted in Chapter 1, disciplinary traditions hold that medical history is a field concerned primarily with human health, which considers animals only in their relations to humans. It positions sick animals within the sub-field of veterinary history, and the study of animal life within the history of biology. While these two fields have paid some attention to the bodies and diseases of zoo animals, ${ }^{10}$ the absence of these animals from medical history scholarship implies that their health had no bearing on human lives. This chapter demonstrates to the contrary. It reveals doctors' efforts to advance zoo animal health for its own sake, how their efforts intersected with veterinary practice and the study of comparative anatomy, and how zoo animals contributed to knowledge of human health. It thereby challenges historians' very notions of medicine as a human-focused endeavour.

The history recorded in this chapter derives from the traces that zoo animals left on the medical historical record. ${ }^{11}$ These traces survive in museum collections and catalogues, press reports, records of medical society meetings, medical journals and textbooks, medical biographies and the zoos' institutional archives. They include the material changes that disease inflicted on animal bodies, and their representation in images, verbal reports and statistics. They also encompass human responses to those changes, which left imprints on human and animal bodies and relationships, the zoos' natural and built environments, and on the careers of medical investigators. Through analysing these traces and the circumstances of their production, the chapter sheds new light on animals' health histories, and on the historical co-constitution of animals, zoos and medicine.

The chapter is divided into halves. Each is structured around a different reason why zoo animal health attracted the attention of human

\footnotetext{
${ }^{10}$ Veterinary accounts include: Jones (1976), Furman (1996). For the history of biology, see Desmond (1985), Burkhardt (1999), Hochadel (2005), Hochadel (2011), Nyhart (2009) pp. 110-7. Nyhart argues that a sense of moral obligation to animals provided an important motivation for maintaining their health, but this was not evident in British zoos at the time.
}

${ }^{11}$ Benson (2011). 
doctors, and explores the interventions they made, and the implications for animals and medicine. The first half revolves around the threat that diseased animals posed to zoos as financially viable institutions devoted to the scientific study of comparative anatomy. It recounts how medical members of the zoological societies that ran the zoos attempted to prevent, manage and learn about animal diseases through the use of three modes of medicine that were typically applied to humans: public health, bedside medicine and hospital medicine. ${ }^{12}$ Their use in the zoo awarded diseased animals a quasi-human status, and refashioned them-in ways shaped by the animals' physical and behavioural characteristics-into victims of their environments, patients and pathological specimens, with some unanticipated implications for human health.

The second half of the chapter explores the zoo's appeal to medical men who were not involved in its maintenance. This appeal lay in the diversity of species, the presence of monkeys (whose zoological proximity to humans was acknowledged long before Darwin) and the zoo's status as a total institution in which animal bodies, behaviours, lifestyles and environments were centrally controlled by humans. Refashioning animals into points of comparison with humans, these doctors used them to gather insights into human health, the general nature of disease, and relationships between species. ${ }^{13}$ This agenda became known as 'comparative pathology'. Emerging at the nexus of medicine, veterinary medicine and comparative anatomy, it was a quite different form of comparative pathology to the experimental, laboratory-based comparative pathology pursued by Pasteur, Koch and others, which dominates existing medical historical literature. ${ }^{14}$ Like the health interventions documented in the first half of the chapter, its analysis reveals that zoo animals exerted a far greater influence on medical knowledge and practice than historians have previously realized.

\footnotetext{
${ }^{12}$ There is copious medical historical literature on these regimes. Key works include: Foucault (1973), Jewson (1976), Hamlin (1998). For an overview, see Bynum (1994).

${ }^{13}$ The concept of 'total institution' is usually attributed to Goffman, who described it as 'a place of residence and work where a large number of like-situated individuals, cut off from the wider society for an appreciable period of time, together lead an enclosed, formally administered round of life' (Goffman 1968) p. 11. While this is a human-centred definition, which Goffman applied to mental hospitals, it resonates with animal life in zoos.

${ }^{14}$ Wilkinson (1992).
} 


\subsection{Disease and Death in the Zoo}

It was not long before the governing councils of the Zoological Society of London (ZSL) and the RZSI discovered the difficulties inherent in maintaining animals exotic to Britain in life and health. Following their creation, in 1828 and 1831 respectively, the societies raised funds by subscription, selected suitable sites for the establishment of zoological gardens, and populated them with animals purchased from overseas suppliers or awarded as gifts. However, these animals were soon beset by disease and death. Despite the day-to-day care provided by zookeepers, the traumatic circumstances of animal capture, long voyages under unsuitable conditions and the conditions of life in the gardens took their toll. Bristol's first elephant cost $£ 270$ but died within two years. Chimps and monkeys were purchased but soon died and were not replaced. ${ }^{15}$ In Dublin, deaths from distemper, heart disease, fighting and 'decline' were reported, ${ }^{16}$ while the inhabitants of London Zoo suffered inflammation, enteritis, lameness, wasting and cold. ${ }^{17}$

The zoological societies did not necessarily regard all of these deaths as problematic. The RZSI attributed some to accidents and others to old age, although the lack of information about natural lifespans made it difficult to define the latter. Council members expected exotic animals to suffer as a result of the British climate and their unnatural surroundings. ${ }^{18}$ Consequently they often assessed mortality in relative rather than absolute terms: the fact that in 1840, deaths in Dublin Zoo were fewer than in London was cause for self-congratulation. ${ }^{19}$ Societies typically drew distinctions between losses that were 'not of importance'-such as small animals and birds, whose individual disappearance had few implications for visitors or the societies' bank balances - and those of greater significance. The latter comprised cases of 'unusual' mortality in which a number of animals died unexpectedly, and so-called 'major' deaths of valuable, popular animals, such as elephants, primates and large carnivores. ${ }^{20}$

\footnotetext{
${ }^{15}$ Green-Armytage (1964) pp. 15, 33.

${ }^{16}$ de Courcy (2009) p. 24.

${ }^{17}$ Medical Superintendent (1838-1841).

${ }^{18}$ Proceedings of the Royal Zoological Society of Ireland, passim. Early attempts by the ZSL to acclimatize certain animals to British soils failed. See Ito (2014) pp. 138-62.

${ }^{19}$ For example: Proceedings of the Royal Zoological Society of Ireland (1840) p. 1.

${ }^{20}$ Proceedings of the Royal Zoological Society of Ireland (1840) p. 1, (1846) p. 38, (1848) p. 52 .
} 
In some ways, these deaths benefited zoological societies by providing their members with exciting opportunities to dissect animal bodies and compare anatomies. Comparative anatomy was a cutting-edge mode of enquiry in the late eighteenth and early nineteenth centuries, which drew on and contributed to ideas about divine providence, man's unique place in nature and how society should be organized. It was grounded in the assumption that unity existed in the midst of diversity; and that there were laws of bodily structure and function that applied equally to humans and animals and could be identified by comparing anatomical similarities and differences across species. There was no uniform approach to comparative anatomy. Perceptions of the relationships between species resonated with ideas about the ideal relationships between different classes of society, the state and its citizens, and God and his subjects. Consequently, the field was often beset with controversy. Prior to the late nineteenth-century transformation of biology and zoology into academic disciplines, formal training in comparative anatomy was delivered primarily through the medical curriculum, and its key sites of investigation were museums and zoological gardens. Indeed, the advancement of comparative anatomy was a prime motivation for the zoos' establishment. ${ }^{21}$ These circumstances help to explain why many medical men became involved in running zoological societies. The opportunities these societies offered for mingling with learned gentlemen and aristocrats who were similarly interested in comparative anatomy provided an additional draw to members of this socially aspiring profession. ${ }^{22}$

Some historians have argued that the zoological societies' enthusiasm for comparative anatomy meant that they welcomed animal death and did little to prevent it. ${ }^{23}$ This claim is not supported by historical evidence. Although dead animals were often of great scientific interest, they had definite drawbacks for the societies' finances. Within a few years of their foundation, the zoological societies of London, Ireland and

${ }^{21}$ Cave (1976), Desmond (1985), Desmond (2001), Cunningham (2010) pp. 295-355. Akerberg notes that c. $40 \%$ of scientific reports emanating from London Zoo in the period 1830-1900 were anatomical in character (Akerberg 2001) pp. 174, 186-90.

${ }^{22}$ Desmond (1989), Brown (2011).

${ }^{23}$ Akerberg (2001) pp. 186-94, Hancocks (2001) pp. 50-1, 73-6, Baratay and Hardouin-Fugier (2002) pp. 131-9, Cowie (2014) pp. 94-8. 
Bristol all faced financial difficulties, to the extent that replacing dead animals threatened their very survival. ${ }^{24}$ According to William Rees, assistant secretary to the ZSL, the deaths of at least one large carnivore each month in 1841-1843 had cost the society $£ 200$ per annum, the equivalent to an investment of $£ 5000$ at $4 \%$ per annum. ${ }^{25}$ While societies could decide not to replace dead animals, this would ultimately rebound on their comparative anatomical projects. It would also reduce income from visitors, who paid to enter London and Bristol Zoos in the hope of encountering rare, exotic animals, some of which had become national celebrities. $^{26}$ Animal disease was similarly problematic because it rendered animals unappealing to visitors but no less costly to maintain. ${ }^{27}$ In order to address this situation and improve the abilities of zoo animals to perform their human-designated roles as public attractions, sources of revenue and scientific specimens, medical members of the zoological societies took steps to improve their health.

The fashioning of zoo animals into medical subjects built on a long tradition of medical engagement with animals in health and disease. It was not unusual for nineteenth-century doctors to dissect and experiment on animals, both to learn about humans and human-animal relationships, and to promote the health of animals as an end in itself. In a horse-drawn society, half of whose members still lived in rural areas in the mid-nineteenth century, there were definite personal benefits to being able to manage animal health. During the eighteenth century, elite equine farriery had attracted converts from human surgery, while physicians and surgeons were drawn to study outbreaks of contagious animal diseases and to promote the improvement of livestock. They also championed the 1791 foundation of Britain's first veterinary school in London, and participated in its activities for decades afterwards. ${ }^{28}$ The zoos provided a new institutional setting and an additional rationale for the expression of these existing interests. Perceiving no obvious distinction between the medicine of humans and animals, medical members

\footnotetext{
${ }^{24}$ Green-Armytage (1964), de Courcey (2009), Ito (2014).

${ }^{25}$ Zoological Society of London (1844) pp. 10-11.

${ }^{26}$ Dublin Zoo was free to enter but relied on visitors for special fundraising events. Probably the most famous celebrity was Jumbo the elephant at London Zoo (Nance 2015).

${ }^{27}$ Zoological Society of London (1848) p. 14.

${ }^{28}$ Woods (2017).
} 
of the zoological societies responded to sick zoo animals through the application of three regimes that they also applied to the management of human health. These will be addressed in turn.

\subsubsection{Public Health}

Growing interest in the health of zoo animals coincided with the emergence of public health as a human medical regime that addressed the health of human populations, especially the urban poor. During the 1830 s and 1840s, the causes of an apparent deterioration in public health were investigated by various medical men and by lawyer Edwin Chadwick, secretary to the Poor Law Commission, whose Report on the Sanitary Condition of the Labouring Population of Great Britain (1842) documented the poor housing and insanitary lives of urban slum dwellers. In attributing disease to dirt, which gave rise to unhealthy miasmas, Chadwick's report constructed the urban poor as victims of their environments, and precipitated the passage of the British government's first Public Health Act in 1848, which awarded powers to clean up nuisances and provide clean water to towns. ${ }^{29}$

Similarly, from the 1830s, the zoological societies' annual reports reveal ongoing concerns about the sanitary condition of zoo animal populations, and perceptions that these creatures were victims of their unhealthy environments. In 1832, physician J.C. Cox probed the relationship between climate and animal constitutions, ${ }^{30}$ making recommendations for the humidity, temperature and vegetation of their enclosures that he later drew on when advising on human health in his volume Hints for Invalids about to Visit Naples. ${ }^{31}$ John Houston, curator of the museum of the Royal College of Surgeons in Ireland, passed on similar observations to the RZSI following his investigations into the causes of zoo animal deaths. ${ }^{32}$ Meanwhile, a correspondent to The Times drew attention to the substandard buildings and damp, muddy enclosures in the ZSL's gardens, and their likely effect on the health of animal inhabitants. ${ }^{33}$

\footnotetext{
${ }^{29}$ Hamlin (1998).

${ }^{30} \operatorname{Cox}(1832)$ pp. 33-8.

${ }^{31} \operatorname{Cox}(1841)$.

${ }^{32}$ Houston (1834).

${ }^{33}$ Spectator (1836).
} 
In response to these observations, the ZSL council began, in the 1840s, to plan new buildings 'with reference to the primary object of preserving the animal in health'. ${ }^{34}$ This meant that without intending to do so, diseased animals shaped the structures that were erected to accommodate them, thereby leaving their traces in the zoo's architecture. Previously, council members had believed that exotic animals had to be protected from the environment, and therefore confined them in heated rooms with a close atmosphere. Now, however, they emphasized the merits of fresh air and ventilation. Their views may have been informed by concurrent proposals to improve the ventilation and cleanliness of hospitals, which also housed large number of bodies in close proximity and were experiencing high death rates. ${ }^{35}$ Certainly, the mid-century drive for fresh air long preceded the work of late nineteenth-century zoo reformers such as Peter Chalmers Mitchell in London and Carl Hagenbeck in Hamburg, who later claimed to have introduced the concept. ${ }^{36}$

In the early 1840s, the ZSL followed the same principle when constructing a new 'carnivore house', with dens open to the fresh air and no artificial heat. It reported that as a result of this 'bold experiment', ${ }^{37}$ the death rate fell, leopards grew fatter, females began to exhibit symptoms of breeding, and appetites increased to such an extent that a tigress and puma unfortunately devoured their companions. Inspired by this result, members turned their attention to the monkey house, where ventilation was restricted and mortality extremely high. They suspended the use of hot-water apparatus and limited the application of artificial heat. Reportedly, this led to a great improvement in health. ${ }^{38}$ Similar interventions were performed in Dublin Zoo, with the same result. ${ }^{39}$

Some thirty years later, in his 1875 lectures on state medicine, SurgeonMajor De Chaumont, the Assistant Professor of Military Hygiene at the Army Medical School, Netley, noted that ventilation in many human dwellings was still just as defective as it had been in the ZSL's unimproved monkey house. ${ }^{40}$ Such statements, like Cox's earlier Hints

\footnotetext{
${ }^{34}$ Zoological Society of London (1851) p. 11.

${ }^{35}$ Granshaw (1992).

${ }^{36}$ Chalmers Mitchell (1929) pp. 189-203, Rothfels (2002).

${ }^{37}$ Zoological Society of London (1844) p. 10.

${ }^{38}$ Zoological Society of London (1845) pp. 12-3.

${ }^{39}$ Proceedings of the Royal Zoological Society of Ireland (1847) p. 47.

40 'State Medicine' (1875).
} 
for Invalids about to Visit Naples, show that the movement of ideas and practices between human and animal health was not entirely one way. In the meantime, however, the ZSL had backtracked on its enthusiasm for open air following numerous deaths from exposure. In 1854-1855, it erected a glazed screen and blinds in an attempt to protect lions from the wind, damp and sudden changes in temperature. ${ }^{41}$ In 1861, ZSL Secretary Philip Sclater was forced to write to the Morning Post to deny public accusations that animals were dying of cold. He claimed that the only 'really valuable' animals lost were three antelopes, and a new house was being constructed for the protection of those remaining. ${ }^{42}$

The notion of miasma as a cause of disease also directed zoological societies' attention to the wider zoo environment, whose subsequent refashioning enabled diseased animals to leave their traces on zoo landscapes and water supplies. From 1848, the ZSL lobbied the Commissioners of Sewers to order the drainage of its site in Regent's Park on the grounds that dampness was giving rise to fogs that injured human and animal inhabitants alike. ${ }^{43}$ On completion of this work in 1853, members eagerly anticipated an improvement in animal health. ${ }^{44}$ The reservoir that supplied the gardens was also reconstructed to manage the 'accumulation of decayed vegetable matter and other impurities ... which ... may possibly have generated some of the attacks of disease which have occurred at various periods and have baffled all other conjecture as to their origin'. ${ }^{45}$ In the later nineteenth century, this sanitary mode of thinking was supplemented and then marginalized by emerging germ theories, which located the source of disease within contaminated bodies rather than environments. ${ }^{46}$ Nevertheless, close confinement and bad air continued to be cited as causes of ill health and death in the London, Dublin and Manchester zoological gardens, and a succession of new houses were erected in efforts to combat the problem. ${ }^{47}$ Writing in $1887, \mathrm{ZSL}$

\footnotetext{
${ }^{41}$ Zoological Society of London (1855) p. 12.

${ }^{42}$ Sclater (1861) p. 5.

${ }^{43}$ Zoological Society of London (1849) pp. 13-4, (1851) p. 16.

${ }^{44}$ Zoological Society of London (1853) p. 13.

${ }^{45}$ Zoological Society of London (1857) p. 6.

${ }^{46}$ Worboys (2000).

${ }^{47}$ Flower (1887), Jennison (1929), de Courcy (2009) pp. 31-42.
} 
Secretary, Professor W.F. Flower, claimed that such improvements contributed not only to the health and strength of animals, but also to their happiness, and therefore to the enjoyment that visitors gained from watching them. ${ }^{48}$

As another aspect of public health, diet attracted considerable attention in mid-nineteenth-century Britain. Newspaper reporting on the Great Famine in Ireland (1845-1852), the Lancashire Cotton Famine (1861-1865) and workhouse dietaries framed hunger as a public rather than a private problem, while German chemist, Justus Liebig, crafted a new science of nutrition which informed medical understandings of dietary intake. ${ }^{49}$ These insights and concerns spilled over to the zoo, where the nutritional needs of zoo animals moulded the activities of keepers and zoological society doctors. ${ }^{50}$ When selecting animal diets, these men took their lead from the classification of animals into carnivores and herbivores. This laid open the possibility of misclassification, as suggested in the case of a ZSL walrus whose failure to thrive was reported in $1868 .^{51}$ Feeding practices also took food type, quality, variety and texture into consideration. However, efforts to provide suitable diets were complicated by a lack of knowledge about, or inability to obtain the foods consumed in the wild, and by the difficulty of preventing feeding by visitors. ${ }^{52}$

In both humans and animals, diet was understood to impact on health in various ways - indirectly, through undermining bodily constitutions, ${ }^{53}$ and also directly, as illustrated in the opening vignette. The post-mortem examination of dead animals revealed its effects. While the rhino's demise was attributed to the misfeeding of Indian corn, ${ }^{54}$ other animals died of scurvy ${ }^{55}$ and emaciation. ${ }^{56}$ Foreign bodies in the digestive tract were not uncommon. A ZSL sea bear was killed by fish hooks, and an ostrich by

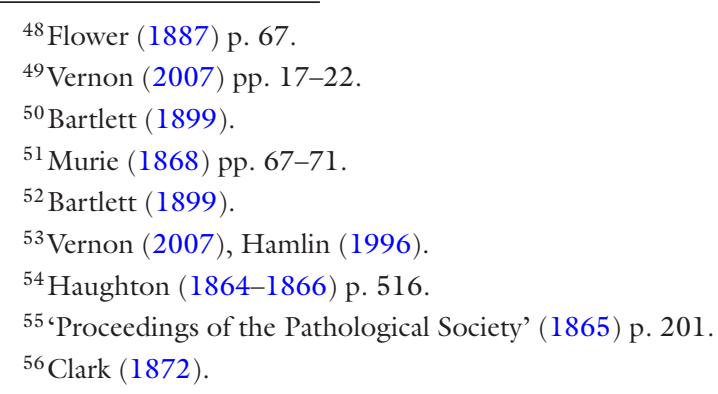


half a gallon of stones and copper coins in its stomach. ${ }^{57}$ Other animals suffered because they were unable to eat the diet provided. The mother of lion cubs born with cleft palates in Dublin in 1873 had received horse bones that were too hard for her to chew. On the recommendation of Dr Samuel Haughton, rabbits were fed instead and the problem did not recur. In an 1873 introductory address to University College Hospital, the surgeon, Mr Erichsen, referred to this episode as an important lesson in how to prevent such defects in human children. ${ }^{58}$ As discussed below, this issue attracted further attention in London during the 1880s.

\subsubsection{Bedside Medicine}

Another medical regime that found expression in Britain's nineteenthcentury zoos was that which historians have termed 'bedside medicine'. This was an individualized system of clinical care applied particularly to elite patients who could afford private medical attention in their homes. It was not the only mode of treating disease. Just as sick people turned usually to family, friends or trusted members of local communities for remedies and advice, so the day-to-day care of sick animals was provided by zookeepers and superintendents. In mid-century Dublin, keepers had their wages docked if animals died or escaped, ${ }^{59}$ while in London they were expected to 'as far as possible obtain a knowledge of the structure and acquaint themselves with the disorders of the animals' ${ }^{60}$ Many keepers were former farm labourers. From informal exchanges of knowledge and close acquaintance with the animals in their care, they learned to identify symptoms of illness and to handle sick animals in ways that sometimes permitted inspections, drug administration and the management of physical injuries. ${ }^{61}$ The expertise of Abraham Dee Bartlett, superintendent of London Zoo from 1859 to 1897, was legendary and extended to surgical interventions, such as the tricky dental operation performed on Obaysch the celebrity hippo, and the removal of broken fangs causing abscesses from the mouths of poisonous serpents-an

\footnotetext{
${ }^{57}$ Murie (1867) pp. 243-44, Darwin and Garrod (1872) pp. 356-63.

${ }^{58}$ Erichsen (1873) p. 413.

${ }^{59}$ de Courcy (2009) p. 20.

60 'Zoological Society of London, Meeting of Council' 22 May 1833.

${ }^{61}$ Burt (2002), Hochadel (2011).
} 
operation that once left fatal marks on the body of a drunken keeper who was attempting to restrain them. ${ }^{62}$

In awarding animals the roles of patients, 'bedside medicine' was superimposed on this regime. Between 1829 and 1842, the ZSL employed a 'surgeon' or 'medical superintendent' to treat their diseases. The post-holder was actually a veterinary surgeon. The first appointee, Charles Spooner, had recently qualified from the London (later Royal) Veterinary College and was known for his anatomical prowess. He agreed to attend the gardens three times a week, and more often when necessary, for a fee of $£ 60$ per annum. ${ }^{63}$ Reportedly, his relationship with the keepers was not entirely amicable and he was replaced in 1833 by William Youatt, a fellow of the ZSL who received $£ 100$ per annum. Youatt was a highly respected though unqualified vet. He ran a large clinic in London's Oxford Street and lectured at London University on the diseases of domestic animals. He and the head keeper inspected the menagerie together twice a week and issued regular, joint reports to council. ${ }^{64}$ Medical members of the ZSL council sometimes attended these inspections and offered their own opinions, diagnoses and suggested remedies - to the irritation of Youatt, who was working with other veterinary reformers to separate the domain of veterinary from human medicine and to limit medical participation in it. ${ }^{65}$

Traces of Spooner's and Youatt's animal patients-who were mostly mammals or valuable birds-are left in their journals, which itemize each patient, their disease, their clinical condition (as deduced largely from symptoms, outward appearances and keepers' reports of recent behaviour) and recommendations for treatment. Usually applied by keepers, therapies ranged from nursing to ointments and medicines aimed at symptomatic relief. ${ }^{66}$ Youatt also published a series of individual case reports in his periodical, The Veterinarian, under the heading 'comparative pathology' (although they featured little in the way

\footnotetext{
${ }^{62}$ Bartlett (1899).

${ }^{63}$ 'Zoological Society of London, Meeting of Council' 1 July 1829.

64 'Zoological Society of London, Meeting of Council' 22 May 1833.

${ }^{65}$ Youatt (1836d, 1836e), Woods (2017).

66 'Surgeon's Journal' (1829-1831), Medical Superintendent (1838-1841).
} 
of comparison). ${ }^{67}$ These records offer rare insights into the health experiences of animal patients, as perceived by their human healers. Youatt diagnosed conditions such as mange, moulting, lameness, paralysis, phthisis, wasting, enteritis, diarrhoea, wounds and abscesses. He documented the demeanour, appetites and appearances of his patients, and expressed humanitarian concern for them, as befitted a supporter of the Royal Society for the Prevention of Cruelty to Animals. He routinely referred to a sick animal as a 'poor fellow'. When ordering the application of yet another caustic blister to a pheasant's skin, he was 'loath to punish the poor bird any more' ${ }^{68}$ His lengthy account of the decline and death of a chimpanzee-which appeared also in the medical presswas shot through with emotion at the animal's plight. ${ }^{69}$

Youatt's reports show that animals did not always cooperate with 'bedside medicine'. For example, a moose deer that he examined on 19 April 1835 was reportedly 'a sadly ferocious fellow, and cannot be handled'. By the 28th of the month the deer would 'no longer take his powders' and two days later was reportedly 'very suspicious of his food and will not eat anything in which medicine is concealed'. His condition fluctuated over the next two months until 'unexpected by any of us' he died. ${ }^{70}$ Another of Youatt's patients, a rhinoceros with colic, did not respond to having his belly rubbed, although he gained some relief from calomel, which Youatt tricked him into consuming by concealing it in a carrot. When the pains resumed, keepers tried to roll the rhino with the aid of ropes and a collar placed around his neck. They also forced three pints of castor oil and half a pint of laudanum down his throat. He struggled to exhaustion and did not respond to the medicine. Youatt thought of administering an enema but it proved 'utterly impossible', and when men tried to drench the rhino with Epsom salts he broke his collar. Nevertheless, he gradually recovered-presumably in spite of rather than as a result of Youatt's interventions. ${ }^{71}$

\footnotetext{
${ }^{67}$ For example: Youatt (1836a).

${ }^{68}$ Medical Superintendent, 14 March 1838, Case 1130.

${ }^{69}$ Youatt (1836d, 1836e).

${ }^{70}$ Youatt (1836a).

${ }^{71}$ Youatt (1836).
} 
Youatt remained in post until 1842, when deteriorating finances led the council to award his responsibilities to the head keeper, reportedly 'without in any degree impairing the general efficiency of that department'. ${ }^{72}$ From then until the twentieth century, veterinarians made only occasional contributions to the health of animals in the gardens, primarily in the surgical treatment of valuable animals, as in 1850, when Royal Veterinary College Principal, J.B. Simonds, worked with a human surgeon to amputate a leopard's leg using chloroform. ${ }^{73}$ 'Bedside medicine' was still provided to valuable, high-profile animals but by medical members of the zoological societies, who occasionally summoned aid from leading members of their profession. In 1850s Dublin, sick animals were identified, diagnosed and treated by whichever RZSI council member was responsible for conducting the weekly inspection of the gardens. Subsequently, this responsibility was assumed by surgeon, RZSI council member and its future secretary the Reverend Professor Samuel Haughton. ${ }^{74}$ In 1860 s London, the naturalist and surgeon Frank Buckland doctored the ZSL's animals in conjunction with Superintendent Bartlett, and turned his house into an honorary animal hospital. ${ }^{75}$ Care was also provided by surgeon James Murie who as shown below, was appointed in 1865 as the ZSL's first prosector. ${ }^{76}$ This was a post that existed in many human hospitals, and involved the performance of post-mortem examinations on human (or, in this case, animal) bodies.

These medical men were clearly convinced that their experiences at the human bedside formed a useful guide to 'cage-side' treatments, and that as a consequence, dedicated veterinary care was rarely required. Their applications of bleeding, medicines and nursing care closely resembled those applied to human patients. ${ }^{77}$ For surgical problems such as tooth abscesses, swollen joints, cataracts and wounds, they applied the principles and techniques of human surgery, and possibly also their knowledge of comparative anatomy. For example, in 1835, Phillip Crampton, surgeon-general of Ireland and fellow of the RZSI,

\footnotetext{
${ }^{72}$ Zoological Society of London (1855) p. 4.

73 'A Leopard' (1850) p. 4.

${ }^{74}$ de Courcy (2009) pp. 33, 41-3.

${ }^{75}$ Bompas (1885).

${ }^{76}$ For example: Murie (1870) pp. 611-5.

${ }^{77}$ Jewson (1976).
} 
performed a tracheotomy on a wapiti after noticing during a visit that it had difficulty breathing. ${ }^{78}$ His colleague, Dr Houston, performed an eye operation to relieve an ostrich suffering from an injury-induced abscess. ${ }^{79}$ Surgeons quickly discovered that animals were more resistant to such interventions than human patients. In 1840, a sick leopard had to be restrained in a net so that a Dr Corrigan could auscultate its chest with a stethoscope.$^{80} \mathrm{~A}$ decade later, when Dr John Snow attempted to apply newly discovered chloroform anaesthesia to a bear so that William White Cooper (later surgeon-oculist to Queen Victoria) could operate on its cataracts, it took several men more than ten minutes to manoeuvre the bear into a position where anaesthesia could be applied. ${ }^{81}$ Likewise, in attempting to perform minor operations on monkeys in London during the 1880s, surgeon John Bland Sutton was impeded by their propensity to struggle and bite. ${ }^{82}$ In these ways, animals moulded their relationships with medical men, and the clinical interventions that were performed on them.

\subsubsection{Hospital Medicine}

Doctors' interest in the health of zoo animals did not end with the failure of preventive or curative interventions. After animals died, they awarded them additional roles as pathological specimens. In London, post-mortem inspection of animals' morbid anatomy was conducted initially on a limited scale by the veterinarians Spooner and Youatt, with the aim of determining why valuable animals had died. ${ }^{83}$ Subsequently, the practice expanded to resemble what historians of human medicine have described as 'hospital medicine'. Emerging in revolutionary Paris and spreading later to England, hospital medicine proceeded through extensive post-mortem examinations on hospital patients. From examining pathological anatomical changes after death and correlating them with the signs and symptoms of disease displayed in life, doctors developed

\footnotetext{
78 'Novel Operation' (1835) p. 2.

${ }^{79}$ Houston (1834) pp. 287-8.

80 'Royal Zoological Gardens' (1840).

81 'An Account of Operations' (1850).

${ }^{82}$ Bland Sutton (1931) p. 142.

${ }^{83}$ Spooner (1832, 1833), Medical Superintendent (1838-1841).
} 
new insights into the identities and relative frequencies of diseases, and how to diagnose them. ${ }^{84}$

Zoos offered unique opportunities for the practice of hospital medicine. The control that they exerted over animals' living conditions and the regular surveillance performed by keepers and the zoological societies generated intimate knowledge of the circumstances and manifestations of disease in life. The examination of animal bodies after death was facilitated by high death rates, the absence of the social taboos that impeded dissection of human bodies, and the zoological societies' existing interest in animal dissection for comparative anatomical purposes. However, 'hospital medicine' in the zoo did not map exactly onto that performed on humans, partly because, as shown above, animals sometimes resisted efforts to examine them clinically in life, which made it difficult to perform anatomo-clinical correlations after death. In addition, animal bodies were sometimes so appealing to the societies' comparative anatomy enthusiasts that attempts to investigate their pathologies were sidelined. In theory, both activities could be performed on the same body, but in practice, they had quite different objectives: pathological anatomical changes showed why an individual animal had died, but its comparative anatomy represented its general zoological type. For the zoological societies, the generation of universal knowledge took precedence over the particular, and so where tensions arose, they privileged comparative over pathological anatomy.

This situation impacted on Youatt's efforts to fashion animals into pathological specimens. Reportedly, the ZSL sometimes asked him to desist his post-mortems in order to preserve certain bodies 'for more detailed dissection, or as a specimen for the museum'. ${ }^{85}$ The post-mortem inspection of a tiger had to be delayed until ZSL members interested in its comparative anatomy had assembled. By the time Youatt opened the body, it gave off a 'stench ... of a particularly oppressive character' that 'exceeded anything I had ever experienced'. 86 On another occasion, members could not wait, and had opened the thorax of a lioness and buried the contents before

\footnotetext{
${ }^{84}$ Bynum (1994).

85 'Zoological Society of London, Meeting of Council' 22 May 1833, Youatt (1836a).

${ }^{86}$ Youatt (1834).
} 
Youatt arrived on the scene, thereby preventing him from confirming or refuting the diagnosis of phthisis that he had made in life. ${ }^{87}$

Surgeon James Murie, who was appointed in 1865 as the ZSL's first prosector, also fell foul of its prioritization of comparative over pathological anatomy. Like Spooner and Youatt, he owed his role at the zoo to its animals' propensity to disease and death. He was required to attend daily and dissect all of the zoo's dead animals in a new room constructed specially for the purpose. As well as determining why animals had died, he had to study their comparative anatomies, and organize the sale of their body parts to dealers, museums, and members of the scientific and medical communities. As revealed by the aforementioned case of the Dublin rhino, the RZSI also engaged in this commercial practice in order to recoup some of the financial losses caused by animal disease and death. In this way, dead zoo animals acquired afterlives beyond the zoo, as subjects of taxidermy, scientific research and museum display. ${ }^{88}$

Murie poured his energies into the development of 'hospital medicine' at the zoo. He kept detailed records of each animal he examined, their symptoms in life where ascertainable, and their pathology after death. He transformed individual cases into collective statistics, which laid bare the immense mortality in the zoo: in 1866, $684(33 \%)$ out of a total 2073 animals perished. Murie also started to develop epidemiological perspectives on zoo animal diseases by identifying the commonest causes of death among different classes of animal, and their seasonality and distribution by age and length of time spent in the gardens. Perceiving no distinction between the causes of death in humans and animals, he analysed the latter using the disease categories drawn up by William Farr at the Registrar General's Office. ${ }^{89}$ He went on to draw lessons for how to improve animal health through public health interventions, such as housing and feeding. ${ }^{90}$ However, the ZSL's Prosectorial Committee was not satisfied with his construction of intricate pathological and statistical analyses of animals and demanded that he turn his attention to comparative anatomical descriptions 'for the interest of

\footnotetext{
${ }^{87}$ Youatt (1836c).

${ }^{88}$ See also Alberti (2011).

${ }^{89}$ Eyler (1979).

90 'Prosector's Report' (1865-1868).
} 
science and the credit of the society'. ${ }^{91}$ Murie proved unable to complete these to the required timetable. After much correspondence, he resigned in 1870 citing ill health. ${ }^{92}$ His successors-A.H. Garrod, W.A. Forbes and F.E. Beddard - neatly sidestepped the tensions between comparative and pathological anatomy by largely ignoring the latter. Appointed on account of their anatomical prowess, they were given a free rein to pursue their interests. The Prosectorial Committee lost interest and hardly met following Beddard's appointment in $1884 .^{93}$

The tensions between pathological and comparative anatomy were not inevitable. As shown in the opening vignette, the Reverend Professor Samuel Haughton succeeded in pursuing these activities simultaneously. He already held the chair of geology at TCD when in 1859 he decided to read medicine. He joined the council of the RZSI in 1860, became honorary secretary in 1864 and then was president from 1885 to $1889 .^{94}$ From 1859 he decided to examine all the animals that died in the Dublin gardens. This enabled him to identify causes of death and their frequency, and to make preventive recommendations, for example by changing diets or improving ventilation..$^{95}$ At the same time he used the bodies to pursue a less utilitarian programme of comparative anatomical research that created traces of animal musculature, as documented in his 1873 volume Principles of Animal Mechanics. ${ }^{96}$ Haughton's ability to avoid the tensions that destroyed Murie may have resulted from his position at the zoo. As secretary and president, he possessed considerably more power than Murie, who was a mere employee.

\subsection{Comparative Perspectives}

The activities described above were primarily performed or directed by medically qualified fellows of the zoological societies. Applying the ideas and practices of human medicine, they awarded animals roles as victims of their environments, patients and pathological specimens.

\footnotetext{
91 'Prosectorial Committee: Meetings' 11 November 1869.

92 'Prosectorial Committee: Meetings' 17 November 1869, 22 February 1870.

93 'Prosectorial Committee: Meetings' passim.

${ }^{94}$ Jessop (1973).

95 'Proceedings of the Pathological Society of Dublin' (1865), Haughton (1864-1866),

Proceedings of the Royal Zoological Society of Ireland (1864) p. 12, (1865) p. 18.

${ }^{96}$ Haughton (1873).
} 
They performed interventions in order to protect the societies' finances, and to ensure that the zoos continued to function as sites for the comparative anatomical investigation of exotic animal bodies. Running alongside these 'in-house' activities were other investigations pursued for quite different purposes, by medical men who were not formally associated with the zoological societies and were often marginal to their profession. These men deliberately sought out dead and diseasedzoo animals and worked to refashion them into points of comparison with humans in the hope of advancing medicine and potentially their careers. In comparison with 'in-house' activities, their work was less concerned with using medicine to shape animals, than using animals to shape medicine.

Their efforts to develop comparative perspectives on disease drew on prevailing approaches to comparative anatomy. As outlined above, this activity was rooted in the premise that unity existed in the midst of species diversity, and sought, through comparative studies of diverse species, to identify underlying laws of bodily structure and function. As the nineteenth century progressed, it drew strength from successive, overlapping scientific and intellectual traditions, notably natural theology at the turn of the nineteenth century, Romantic naturphilosophie, cell theory (as developed by Schwann and elaborated by Virchow), Charles Darwin's theory of evolution and, in the 1870s, Ernest Haeckel's evolutionary morphology (which sought to determine relations between organisms by tracing them back to common ancestors). ${ }^{97}$ Meanwhile, a general physiology that evolved separately from medically oriented physiology likewise attempted to extract general laws from the diversity of animal life. ${ }^{98}$ The notion of disease as 'life gone wrong', which gained strength mid-century through Virchow's work, facilitated the incorporation of pathology into this comparative, biological project, while

\footnotetext{
${ }^{97}$ Darwin (1868) pp. 1-27, Jacyna (1984a, 1984b), Desmond (1989), Nyhart (1995).

${ }^{98}$ Nyhart (1995), Logan (2002). London Zoo merits further study as a site of medical physiological enquiry. Richard Quain and John Sibbald used its reptiles to work out the source of heart sounds, while Alfred Wiltshire, lecturer in obstetrics at St Marys Hospital London, used a range of species to study menstruation. Wiltshire (1883) pp. 446-8, 500-2, Wiltshire (1884) pp. 301-5, 'Obituary’ (1905).
} 
Darwin's musings on the inheritance of disease brought an additional, evolutionary dimension to it. ${ }^{99}$

Proceeding through the dissection, observation and comparison of animal bodies, the activity known as 'comparative pathology' bridged medicine and the increasingly professionalized and institutionalized discipline of biology. It encompassed attempts to work out the general nature of disease, to identify species differences in the expression of disease, and to learn something about disease in humans from its expression in the lower animals. Its practice meant that as the century progressed, spontaneously diseased animals continued to attract medical attention, and medical men continued to speak authoritatively about them. Its genealogy challenges historians' claims that it was the rise of germ theory in the 1860s and 1870s that brought human and animal diseases within the same frame of reference by demonstrating that infectious agents could spread between them. ${ }^{100}$ While bacteriology did stimulate a new form of 'comparative pathology', which attempted to work out, through laboratory-based experiment, the relationships between infectious diseases in humans and animals, there was already a rich observational tradition that went by the same name. Largely overlooked by historians, it continued to be practised alongside the experimental version. ${ }^{101}$

The zoo was a key site for the pursuit of this comparative pathology. Its scientific mission and eminent medical figures meant that medical investigators found it easier to access than other centres of animal populations such as farms, stables and dairies. Comparative work was facilitated by the unparalleled diversity of animal inhabitants, by the presence of primates which were zoologically proximate to humans, and by the fact that zoo animals - like many humans-lived 'unnatural' lives in overcrowded, unhealthy environments, and died frequently from disease. Interest in comparative pathology was not confined to the medical men who conducted investigations in the zoo. These investigators often presented specimens of diseased zoo animal bodies to meetings of medical societies, particularly the pathological societies that sprang up across Britain from the 1830s in

\footnotetext{
${ }^{99}$ Virchow (1860), Aitken (1888), Pagel (1945), Churchill (1976).

${ }^{100}$ Wilkinson (1992), Hardy (2003a).

${ }^{101} \mathrm{~A}$ rare account is offered by $\mathrm{Li}(2002)$.
} 
response to the development of hospital medicine. ${ }^{102}$ From here, some specimens found their way into medical museums, where they were used to illustrate general pathologies that occurred in all mammals, such as arthritis or fracture repair. ${ }^{103}$ Verbal descriptions entered medical lectures, textbooks and articles published in the medical press. This shows how even after their deaths, diseased animals retained the capacity to make a difference to human medicine.

\subsubsection{The Pursuit of Comparative Pathology}

One of the earliest practitioners of zoo-based comparative pathology was John Houston, surgeon to the city of Dublin hospital and curator of the museum of the Royal College of Surgeons in Ireland. Before his untimely death in 1845 , he made numerous dissections of animals that had died in Dublin Zoo. Drawing analogies between the pathologies they displayed and those found in humans, ${ }^{104}$ he incorporated specimens of their bodies into his museum, including a 'series of the comparative pathology of the lungs ... so far complete as to afford examples, in the lower animals, of most of the diseases to which the lung of the human being is liable'. This featured a lynx, two deer, two seals, a wild boar, a goose, a bear and a spider monkey. ${ }^{105}$

In London, enquiries of a similar nature were pursued during the 1850s by Edwards Crisp, a general practitioner, whose failed attempt to elevate his status to consulting physician led him to wage war on the medical establishment. Unable to secure the hospital position he needed to advance his career, he looked instead to diseased animals. He kept a small menagerie in his Chelsea garden, used his farming background to gain access to livestock, and sought out the rich resources of London zoo. ${ }^{106}$ Later dubbed a 'pioneer of the study of comparative pathology', ${ }^{107}$ he was convinced that 'the nature of the diseases of man will not

${ }^{102}$ For example, see Transactions of the Pathological Society of London, which from 1854 contained a section entitled 'Diseases of the Lower Animals'.

${ }^{103}$ For example: Clarke (1891), Keith (1910).

${ }^{104}$ Houston (1834) pp. 287-8.

105 'Scientific Intelligence' (1843) pp. 209.

${ }^{106}$ Dobson (1952).

107 'Annual Report of Council' (1883) p. xix. 
be thoroughly understood, nor appropriately treated, until the deviations from normal structure are fully investigated in plants and in the lowest grade of animals' ${ }^{108}$ Although he did not actually conduct experiments on animals, Crisp used their rising prominence within continental physiology to generate rhetorical support for his activities, ${ }^{109}$ claiming in 1852 that 'All the great discoveries in physiology have been made by experiments upon living animals in a state of health; but why should not their diseased conditions be turned to account? Why may not brute pathology hereafter clear up some of the doubts and difficulties of our art?'110

In 1851, the ZSL granted Crisp permission to examine all of its dead animals. He acted in the capacity of honorary pathologist for at least a decade before Murie's appointment as prosector. Simultaneously, he pursued many anatomical and physiological enquiries. He presented his findings frequently to the ZSL, various medical societies and in numerous publications, including his lengthy 1855 account of the spleen, which recounted the size and appearance of 334 spleens obtained from mammals, birds, fish and reptiles. ${ }^{111}$ His systematic recording of the causes of death and their relative frequency resembled hospital medicine, but his stated ambition (which was only partially realized) was to work out how animal pathology differed from that of humans. ${ }^{112}$

Crisp's stay at London Zoo overlapped with that of parasitologist Thomas Cobbold, another marginal medical man who was struggling to make his mark through the study of parasitic animals, which he regarded as contributors to, but rarely the sole causes of, death. ${ }^{113}$ He spent 1857-1860 attempting to harvest and classify parasites found in the bodies of their zoo animal hosts. ${ }^{114}$ Meanwhile, in Manchester, Samuel Bradley, a young lecturer in comparative anatomy and author of a manual on the subject, was drawn to examine the bodies of animals that had died in Manchester's Belle Vue Zoological Gardens. He echoed Crisp in his stated rationale: 'So much light has been thrown upon

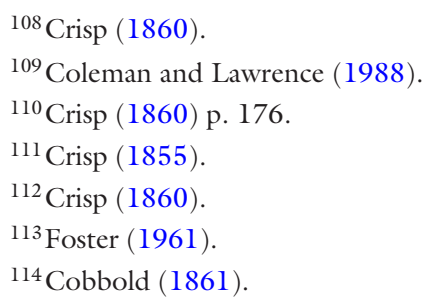


human physiology by the study of comparative physiology and experiments ... that we may reasonably expect that a proportionate increase of light will be thrown upon the knowledge of human pathology by the observation of the diseases which affect the lower animals.' His investigations were particularly concerned with disease aetiology. Referring to the 'unnatural lives' of many zoo animals, he identified bad air and improper food as key factors in the deaths of many mammals, birds, reptiles and fish. ${ }^{115}$ This finding drew on, and perhaps informed his work among the Manchester poor, which led to clashes with the Poor Law Guardians over their treatment. ${ }^{116}$

A decade later, new investigations were launched within the zoo by the Pathological Society of London (PSL). Established in 1846 for the 'cultivation and promotion of pathology by the exhibition and description of specimens, drawings, microscopic preparations, casts or models of morbid parts', the PSL was one of London's most popular medical societies, with members drawn from all ranks of the profession. ${ }^{117}$ Its meeting reports and annual Transactions reveal a long tradition of fashioning animals into pathological material. In 1879, its president, Jonathan Hutchinson (a senior London surgeon who was convinced that comparative pathology could shed light on the diseases of humans ${ }^{118}$ ) proposed to take forward suggestions made by his recently deceased predecessor, Charles Murchison, to pay more dedicated attention to them. ${ }^{119}$ The men were partly inspired by recent epidemiological and bacteriological investigations that had implicated animals in a series of human diphtheria outbreaks. ${ }^{120}$ However, since the PSL was a generalist society populated by clinicians, its members preferred to conduct enquiries not in the laboratory, where an experimental form of comparative pathology was emerging, but in the zoo, an institution they saw as

\footnotetext{
${ }^{115}$ Bradley (1869).

116 'Bradley, Samuel Messenger'.

${ }^{117}$ Butlin (1896).

${ }^{118}$ Hutchinson was best known for his work on dermatology, neurology and syphilis. As editor of the British Medical Journal, 1869-1871, he established a regular column on comparative pathology. Hutchinson (1865) p. 296, Hutchinson (1946).

119 'Pathological Society of London: Annual General Meeting' (1879).

${ }^{120}$ Power (1879) pp. 546-51.
} 
analogous to the human hospital. A PSL committee was appointed and charged with 'exhibiting and reporting on specimens of diseases and injuries in the lower animals'. ${ }^{121}$ Crisp was instated as a member but died shortly afterwards. ${ }^{122}$ W.H. Flower, president of the ZSL, expressed support for the initiative, ${ }^{123}$ as did the British Medical Journal, ${ }^{124}$ which echoed the PSL's hopes that 'soon much further light will be thrown on some diseases of man'. ${ }^{125}$

The PSL appointed recently qualified surgeon, John Bland Sutton, to conduct investigations on its behalf. The son of a taxidermist, who had paid his way through medical school by working as a demonstrator and private teacher in anatomy, he was attracted to dead animals by his interest in pathological anatomy and his desire to advance his career. ${ }^{126}$ He incorporated the zoo's animal inhabitants into a wider research programme that involved the dissection of some 12,000 human and animal subjects between 1878 and 1886 . The investigation enabled him to mingle with socially elevated members of the ZSL and to win invitations to present at their meetings and to London's many medical societies, whose published reports brought his name before the wider profession. ${ }^{127}$ Diseased animals thereby contributed to his career progression. In 1886 he was appointed assistant surgeon to the Middlesex Hospital, and laid aside his work at the zoo. Subsequently, he became consulting surgeon, president of the Royal College of Surgeons from 1923 to 1925, and a baronet. $^{128}$

Initially, Bland Sutton echoed the PSL in emphasizing that the goal of his research programme was to advance human, not animal health: 'In merely recording the diseases of wild animals in confinement little is to be gained, but in elucidating the diseases of man Comparative Pathology will act as a side light of no mean power'. ${ }^{129} \mathrm{He}$ approached

\footnotetext{
121 'Pathological Society of London: Sub-committee meeting' (1881).

122 'Pathological Society of London: Council meeting' (1881).

${ }^{123}$ Flower (1881).

124 'Medical Societies' (1882).

125 'Pathological Society of London' (1882).

${ }^{126}$ Bland Sutton (1931).

${ }^{127}$ For example: Bland Sutton (1884b) pp. 177-87, (1884c) pp. 88-145.

${ }^{128}$ Bland Sutton (1931).

${ }^{129}$ Bland Sutton (1883b).
} 
disease anatomically, by organ system: dental, circulatory, reproductive, and so on. For each system he described the types of pathology displayed by mammals, particularly monkeys, with occasional references to fish, reptiles, amphibians and birds. His findings reinforced the human-animal analogy by illustrating how, when subjected in the zoo to living conditions that approximated those of humans, animals suffered from varieties of the same diseases. ${ }^{130}$

Subsequently, Bland Sutton adopted a less human-centred outlook. Influenced by Haeckel's evolutionary morphology, by debates between Virchow and Weismann on the inheritance of acquired (pathological) characteristics, ${ }^{131}$ and by observations on animals which suggested that conditions regarded as pathological in one species might be natural in another, ${ }^{132}$ he began to conceive of disease as a product of evolutionary forces: 'The same laws which regulate physiology rule pathology ... therefore the laws of evolution apply to pathology as well as to the ordinary events of animal life'. ${ }^{133}$ Disease could also potentially drive evolution. For example, pathological processes such as hypertrophy (overgrowth of tissues), which were-according to the widely held belief in the inheritance of acquired characteristics-passed on to the next generation, could play a role in the differentiation of species. ${ }^{134}$ Bland Sutton described the study of such matters as 'zoological pathology', and 'general pathology in its fullest sense'. It was a branch of biology that could only be advanced through looking at species other than humans. ${ }^{135}$ Like the comparative pathology which informed it, this 'evolutionary pathology' was not exclusive to Bland Sutton, but his findings were uniquely informed by his relationships with zoo animals. ${ }^{136}$

\footnotetext{
130 'Pathological Society of London' (1887).

${ }^{131}$ Churchill (1976).

${ }^{132}$ Bland Sutton (1890) p. 4.

${ }^{133}$ Bland Sutton (1886) p. 376.

${ }^{134}$ Bland Sutton (1885).

${ }^{135}$ Bland Sutton (1890) p. 12.

${ }^{136}$ Other iterations include Williams (1888) and Hutchinson (1892). There was another form of evolutionary pathology that was primarily concerned with the evolution of germs. It can be viewed as the corollary of the other, experimental form of comparative pathology. See Bynum (2002), Zampieri (2006), Buklijas and Gluckman (2013).
} 


\subsubsection{Tuberculosis and Rickets}

Medical men were most interested in the diseases of zoo animals that were analogous to important human diseases. Cancer, reproductive, dental, respiratory and bone diseases were all noted, but tuberculosis and rickets attracted particular attention. Tuberculosis or phthisis was the commonest cause of death in humans during the mid-nineteenth century. Prior to its definition as a bacterial disease in the 1880 s, it was typically identified through the post-mortem appearance of characteristic 'tubercules' in the lungs and elsewhere in the body. ${ }^{137}$ Described in 1846 as the 'bane of the zoological gardens', ${ }^{138}$ it was discovered through post-mortem examination to be the cause of death of virtually every monkey in captivity. ${ }^{139}$ This finding reinforced perceptions of monkeys' proximity to humans on the zoological scale, and led John Simon, the Medical Officer of Health for London, to comment in 1850 that with 'the dignity of standing next to man' came the 'inconvenience of this very human liability'. ${ }^{140}$

Investigators detected certain differences in the appearance of monkey lungs compared with those of humans who died from tuberculosis, which led the editor of The Lancet to apply ideas about comparative anatomy to pathology: 'was there a certain order in the series of diseases through which the human form passes, bearing some analogy with the gradual evolution of its organization?'141 Others were less concerned with the differences than the similarities. Houston's colleague Dr Harrison suggested that tuberculosis in captive monkeys was 'a sort of analogous experiment' that permitted the extrapolation of observations to humans, and vice versa'. ${ }^{142} \mathrm{He}$ also showed that monkeys were not the only victims of 'tubercle'. Listing the various mammals and occasional birds that he had identified as having died from the disease in Dublin Zoo, he blamed the 'unnatural' conditions of confinement such as poor food and lack of exercise, and claimed that the solution lay in

\footnotetext{
${ }^{137}$ Worboys (2000) pp. 193-234.

${ }^{138}$ Bulley (1846).

${ }^{139}$ Harrison (1837).

${ }^{140}$ Simon (1850).

${ }^{141}$ Editorial (1834) p. 147, Houston (1834) pp. 285-6.

${ }^{142}$ Harrison (1837) p. 227.
} 
improved diet and housing. He went on to argue for the further cultivation of comparative pathology, which promised, like comparative anatomy, to extend and confirm knowledge of the human species. ${ }^{143}$

During the $1860 \mathrm{~s}$, as post-mortem examinations on zoo animals became more systematic, and pathological understandings of 'the tubercle' more restricted, the belief that tuberculosis was the commonest cause of monkey death in captivity began to be challenged. ${ }^{144}$ Nevertheless, it remained an important reference point for the disease in humans, and was used to draw attention to the poor conditions in which both human and animal victims lived. For the asylum doctor, William Lauder Lindsay, there was a clear parallel between its occurrence in humans living in overcrowded dwellings, workhouses, barracks and asylums, and in monkeys in the zoo. Elsewhere, the zoo was compared to a factory whose lack of light and air rebounded on the health of its inhabitants. ${ }^{145}$ When a Royal Commission sat in 1875 to consider the regulation of animal experiments, its members suggested to Alfred Garrod, ZSL prosector, that the zoo was a gigantic pathological experiment, of which death by tuberculosis was the result. Garrod admitted that the disease was extremely common and was generated by the conditions in which animals lived. ${ }^{146}$ Their habitation in the zoo had transformed them from wild, foreign creatures into domesticated slum dwellers, analogous to the urban poor. While such ideas about the causation of tuberculosis did not disappear, the zoological breadth of its expression was subsequently eclipsed by Koch's 1882 discovery of a bacterial cause, which focused attention more narrowly on its transmission between humans, cows and birds. ${ }^{147}$

Rickets, which caused softening and deformities of the bones, was another major human health problem, especially among poor children residing in industrial towns. Heredity, early weaning, improper diets, poor hygiene, and a lack of fresh air and sunlight were all implicated, as was syphilis in the 1880 s, but much uncertainty surrounded their

\footnotetext{
${ }^{143}$ Harrison (1837).

${ }^{144}$ Crisp (1860) p. 178, 'Proceedings of the Pathological Society of Dublin' (1865).

${ }^{145}$ Lauder Lindsay (1878), Alexander (1879).

${ }^{146}$ Garrod (1876).

${ }^{147}$ Worboys (2000).
} 
relative contributions. ${ }^{148}$ By mid-century, rickets had been identified in animals and similar causes invoked. ${ }^{149}$ Drawing no distinction between the disease in humans and monkeys, George Humphrey used a monkey skeleton to illustrate its human pathology in his 1850 surgical lectures to Cambridge University. ${ }^{150}$ Subsequently, the PSL received reports of rickets in dogs, ${ }^{151}$ pheasants, and an ostrich from London Zoo. ${ }^{152}$ In 1880, it held a lengthy discussion about the disease, and invited Edwards Crisp to comment on how it affected the lower animals. Crisp reported that domestic animals were rarely affected because they were generally better fed and cared for than the human poor. However, he noted that nearly all of the lions born at the zoo had soft bones, and most died before reaching maturity. ${ }^{153}$

On commencing his investigations at London Zoo, Bland Sutton was astonished by the frequency of rickets. ${ }^{154}$ It proved to be the second most common cause of death in the 100 monkeys he examined in the 14 months from December 1881. ${ }^{155}$ Subsequently he reported its presence in half of the zoo's dead carnivores, as well as in many rodents, birds and lizards. ${ }^{156} \mathrm{He}$ concluded that its incidence among wild animals in captivity was similar to, if not greater than that in human children. ${ }^{157}$ By this time, medical scientists working in laboratories had made various attempts to transform animals into experimental 'models' of rickets in the hope of using them to learn more about the disease in humans. However, the results were either negative or confusing. ${ }^{158}$ Zoo animals-particularly monkeys - that suffered spontaneously from the disease seemed to offer more promising opportunities to advance

\footnotetext{
${ }^{148}$ Hardy (2003b) pp. 337-40.

149 'Birmingham Pathological Society' (1843).

${ }^{150}$ Humphry (1850).

${ }^{151}$ Dick (1863).

152 'The Pathology of Rickets' (1881) p. 332.

153 'The Pathology of Rickets' (1881) pp. 313-91.

${ }^{154}$ Bland Sutton (1883a) pp. 312-22.

${ }^{155}$ Bland Sutton (1883b).

${ }^{156}$ Bland Sutton (1884a).

${ }^{157}$ Bland Sutton (1884a) p. 364.

158 'The Pathology of Rickets' (1881).
} 
knowledge. In reporting about them, Bland Sutton also awarded them roles as disease victims and described their disease experiences. He noted that the first sign of the disease in monkeys was reduced activity. Then the lower limbs became paralysed. Monkeys responded by using their arms as crutches until these began to bow under the weight. Eventually they became paraplegic, and suffered incontinence and priapism. Death intervened after three to four months, usually from bronchitis. ${ }^{159}$

As pathological specimens, monkeys revealed to Bland Sutton the different forms of rickets occurring at different ages. From the microscopic appearances of their bones, he drew parallels with the disease as it developed in humans. ${ }^{160} \mathrm{He}$ also developed epidemiological analogies between the conditions of animal life in the zoo and those experienced by human sufferers, and attempted clinical interventions on lions, which he awarded dual roles as patients and human analogues. Whereas Dublin Zoo's lion-breeding 'industry' was celebrated for the prolificacy of its dams and ability to rear cubs to maturity, in London, many cubs were born with cleft palates and did not survive for long. Others developed signs of rickets after keepers removed them from their mothers for fear of harm. Bland Sutton noted that both adults and cubs were typically fed on old horse carcasses, the bones of which were generally too tough for their teeth. When he fed pregnant lions with goat flesh and soft bones, cleft palates in the offspring did not occur. Moreover, rickety cubs quickly recovered when pounded bones and cod liver oil were added to their diet. Their environment was kept constant in all other ways, with the same amount of air, light and warmth as before. ${ }^{161}$

Bland Sutton did not publish a formal account of these findings, perhaps because from the zoo's perspective, cod-liver oil supplements cost as much as a replacement lion. ${ }^{162}$ There were no long-term changes in feeding practices, and the disease continued to occur, as shown by the continuing deposition of rickety lion skeletons in the Royal College of Surgeons museum. ${ }^{163}$ However, some medical men became very excited

\footnotetext{
159 'Pathological Society of London' (1883).

${ }^{160}$ Bland Sutton (1883a) pp. 312-22.

${ }^{161}$ Cheadle (1882).

${ }^{162}$ Bland Sutton (1931).

${ }^{163}$ For example: 'Skull, Rickets, Osteomalacia' (1947).
} 
by his findings. Speaking at the Diseases of Children section of the British Medical Association's 1888 Annual Meeting, Dr Cheadle, senior physician to the Great Ormond Street Hospital for Sick Children, declared Bland Sutton's dietary experiment 'a crucial one, and ... conclusive as to the chief points in the aetiology of rickets' ${ }^{164}$ It showed that rickets occurred when diets were deficient in fat and bone salts. This became the accepted view of the disease. Rickety lions began to feature in discussions of human rickets and infant feeding practices. They also provided the jumping-off point for Edward Mellanby's subsequent discovery that the key antirachitic component was a substance found particularly in animal fat, later named fat-soluble vitamin D. ${ }^{165}$ In this way, spontaneously diseased zoo animals became unwitting contributors to human health.

\subsection{Conclusion}

This chapter has provided an overview of the health and medicine of the animals that inhabited Britain's zoos during the mid- to late nineteenth century. Contrary to existing historical accounts, which claim that animal health was neglected in this period and that few medical interventions took place, it reveals wide-ranging, ongoing attempts by medical men to understand, prevent and treat animal disease. By turning the spotlight onto these interventions, the circumstances that gave rise to them, and their implications for participating humans and animals, it offers new perspectives on the interlinked histories of zoos, animals and medicine.

We have seen how zoos impacted on, and were moulded by, the health experiences of their animal inhabitants. Methods of animal housing, feeding and management precipitated ailments such as rickets, tuberculosis and digestive upsets, which caused much animal suffering and frequently death. To the zoological societies, these events threatened the zoos' finances and its scientific activities, while to certain external medical men, they offered prospects of scientific and career advancement. The unanticipated occurrence of these diseases prompted the medicalization of zoos-their transformation into sites for medical

${ }^{164}$ Cheadle (1882) p. 1146.

${ }^{165}$ Chesney and Hedberg (2010). 
research and practice. This, in turn, prompted wider transformationsin the zoos' physical structures as post-mortem rooms and more sanitary animal enclosures were built; in their 'natural' landscapes as unhealthy swamps were drained; and in their social organization, as new staff were employed to manage health and investigate disease. The health of zoo animals therefore provides a unique perspective on the history of the zoo and its animal inhabitants.

In health, disease and death, zoo animals inspired medical men to engage with them, both directly within the zoo, and remotely via the traces they left on the medical record. This chapter has revealed how both humans and animals were produced through these relationships. Animals were transformed into patients, victims of their environments, pathological material, and points of comparison across species, while human doctors became healers and investigators of animals. In the process, perceptions of what it meant to be human or animal changed. 'In-house' efforts to improve animal health proceeded on the basis that animals were sufficiently close to humans to permit the application, by doctors, of ideas and practices drawn from human medical contexts. In practice, however, animals' resistance to handling and their unusual anatomies-which attracted medical attention independently of the pathologies they displayed-placed limits on the wholesale importation of human medicine into the zoo. Likewise, while investigations into comparative pathology reinforced notions that humans and animals (particularly monkeys) were sufficiently similar to allow deductions about the former to be drawn from the latter, they also highlighted key differences that were attributed to, and served to consolidate ideas about, their evolutionary relationships. In these ways, the practice of medicine within the zoo simultaneously brought humans and animals closer together, and demarcated the distances between them.

Medical interventions in the zoo also had implications for animal, and to a lesser extent, human health. Some of the zoos' more valuable mammalian inhabitants probably did benefit from zoological society efforts, especially those directed towards environmental improvements. Mortality statistics are not particularly useful in revealing such benefits because they refer to all species. Also, it should be noted that without medical interventions, mortality rates may have been even higher. Rickets provides the best example of a disease whose management in humans was advanced through investigations performed on zoo animals. However, this chapter has provided many other examples of doctors 
drawing unanticipated lessons for human health from their experiences in the zoo.

As the zoo became medical, so medicine became zoological, extending beyond its typical human targets to encompass an array of vertebrate species, which shaped medicine in ways that are not captured by its existing histories. In attempting to promote the health of animals as an end in itself, medical members of zoological societies engaged in activities that historians have tended to regard as 'veterinary' in character. However, they were not viewed in this way at the time: while zoological societies sometimes relied on vets such as Spooner and Youatt, leadership in the management of animal health was provided by their medical members, whose actions suggest that they did not perceive medicine to be bounded by species. Nor did medical visitors to the zoo, who studied diverse spontaneously diseased animals in their efforts to identify the fundamental processes of disease and its similarities and differences across species. Emerging from comparative anatomy and physiology, and straddling the border between medicine and biology, their 'comparative pathology' was much more zoological than the experimental version that features in the existing historical literature. The latter focused largely on rodents, dogs and monkeys, whose similarities with humans were assumed rather than subjected to empirical investigation.

This analysis of health and medicine in the zoo therefore reveals the multispecies dimensions of British medicine in the mid- to late nineteenth century, the fluidity of its boundaries with veterinary medicine and biology, and its historically significant-yet almost completely overlooked-spaces, practices and participants. It shows that in this period, medicine was not a purely human-centred endeavour; nor was its interest in animals restricted to what their experimentally manipulated bodies could reveal about human health and disease. Within the zoo, animals were medical subjects in their own right, whose management brought changes to the institution. Their similarities to and differences from humans both informed, and emerged through their investigation and treatment, while their participation in human medicine had important implications for its ideas, practices and personnel. Animals, medicine and zoos thereby shaped and reshaped each other, to the extent that studying any one in isolation from the others can provide only a partial understanding of history. 


\section{BIBLIOGRAPHY}

“A Leopard Under The Influence Of Chloroform.” Times, June 15, 1850: 4. Adelman, Juliana. "Animal Knowledge. Zoology and Classification in Nineteenth-century Dublin." Field Day Review 5 (2009): 109-21.

Aitken, William. "On the Progress of Scientific Pathology." British Medical Journal 2 (1888): 348-58.

Akerberg, S. Knowledge and Pleasure at Regent's Park: The Gardens of the Zoological Society of London During the Nineteenth Century. Sweden: Umea University, 2001.

Alberti, Samuel (ed.). The Afterlives of Animals: A Museum Menagerie. University of Virginia Press: Charlottesville, 2011.

Alexander, R. "Practical Notes on the Treatment of Phthisis." Lancet 114 (1879): 760-1.

"An Account of Operations for Cataract on Bears." Morning Post, December 13, 1850: 2 .

"Annual Report of Council." Transactions of the Pathological Society of London 34 (1883): xix.

Baratay, Eric and Elizabeth Hardouin-Fugier. Zoo: A History of Zoological Gardens in the West. London: Reaktion, 2002.

Bartlett, A.B.E. Wild Animals in Captivity: Being an Account of the Habits, Food, Management and Treatment of the Beasts and Birds at the Zoo. London: Chapman and Hall, 1899.

Benbow, S.M.P. "Death and Dying at the Zoo." Journal of Popular Culture 37 (2004): 379-98.

Benson, Etienne. "Animal Writes: Historiography, Disciplinarity, and the Animal Trace." In Making Animal Meaning, edited by L. Kalof and G. M. Montgomery, 3-16. East Lansing, MI: Michigan State University Press, 2011.

"Birmingham Pathological Society." Provincial Medical and Surgical Journal 7 (1843): 76-9.

Bland Sutton, John. "Rickets in a Baboon" and "Bone Disease in Animals." Transactions of the Pathological Society of London 34 (1883a): 312-5, 315-22.

Bland Sutton, John. "On the Diseases of Monkeys in the Society's Gardens." Proceedings of the Zoological Society London (1883b): 581-6.

Bland Sutton, John. "Observations on Rickets, \&c., in Wild Animals." Journal of Anatomy and Physiology 18 (1884a): 362-87.

Bland Sutton, John. "On the Diseases of the Carnivorous Mammals in the Society's Gardens." Proceedings of the Zoological Society London (1884b): $177-87$. 
Bland Sutton, John. "Comparative Dental Pathology." Odontological Society Transactions 16 (1884c): 88-145.

Bland Sutton, John. "On Hypertrophy and its Value in Evolution." Proceedings of the Zoological Society of London (1885): 432-45.

Bland Sutton, John. An Introduction to General Pathology. Philadelphia: Blakiston \& Son, 1886.

Bland Sutton, John. Evolution and Disease. London: Walter Scott, 1890.

Bland Sutton, John. The Story of a Surgeon. London: Methuen, 1931.

Bompas, George. Life of Frank Buckland. 2nd ed. London: Smith, Elder \& Co, 1885 .

Bradley, Samuel. "Notes on the Diseases of Animals in a State of Confinement." Lancet 93 (1869): 708-9.

“Bradley, Samuel Messenger." Platt's Lives of the Fellows online, http://livesonline.rcseng.ac.uk/biogs/E000950b.htm.

Brown, Michael. Performing Medicine: Medical Culture and Identity in Provincial England, c.1760-1850. Manchester: Manchester University Press, 2011.

Buklijas, T. and P. Gluckman. "From Evolution to Evolutionary Medicine." In The Cambridge Encyclopaedia of Darwin and Evolutionary Thought, edited by Michael Ruse, 505-14. Cambridge: Cambridge University Press, 2013.

Bulley, F.A. "Retrospective Address Read at the Fifth Anniversary of the Reading Pathological Society." Provincial Medical and Surgical Journal 10 (1846): 425-8.

Burkhardt, Richard. "Ethology, Natural History, the Life Sciences, and the Problem of Place." Journal of the History of Biology 32 (1999): 489-508.

Burkhardt, Richard. "Constructing the Zoo: Science, Society and Nature at the Paris menagerie, 1794-1838." In Animals in Human Histories: The Mirror of Nature and Culture, edited by M. Henninger-Voss, 231-57. Rochester, NY: University of Rochester Press, 2002.

Burt, Jonathan. "Violent Health and the Moving Image: The London Zoo and Monkey Hill." In Animals in Human Histories: The Mirror of Nature and Culture, edited by M. Henninger-Voss, 258-94. Rochester, NY: University of Rochester Press, 2002.

Butlin, Henry. "An Address on the Jubilee of the Pathological Society of London." British Medical Journal 2 (1896): 1221-4.

Bynum, W. The Science and Practice of Medicine in the Nineteenth Century. Cambridge: Cambridge University Press, 1994.

Bynum, W. "The Evolution of Germs and the Evolution of Disease: Some British Debates, 1870-1900." History and Philosophy of the Life Sciences 24 (2002): 53-68. 
Cave, A.J.E. "The Zoological Society and Nineteenth Century Comparative Anatomy." In The Zoological Society of London 1826-1976 and Beyond, edited by Professor Lord Zuckerman, 49-66. London: Academic Press, 1976.

Chalmers Mitchell, Peter. Centenary History of the London Zoological Society. London: Zoological Society of London, 1929.

Cheadle, Dr. "Introductory Address: A Discussion on Rickets." British Medical Journal 2 (1882): 1145-8.

Chesney, Russell and Gail Hedberg. "Metabolic Bone Disease in Lion Cubs at the London Zoo in 1889: The Original Animal Model of Rickets." Journal of Biomedical Science 17 (2010): suppl. 1. S36-9.

Churchill, Frederick. "Rudolf Virchow and the Pathologist's Criteria for the Inheritance of Acquired Characteristics." Journal of the History of Medicine and Allied Sciences, 31 (1976): 117-48.

Clark, John. "Notes on the Visceral Anatomy of the Hippo." Proceedings of the Zoological Society of London (1872): 185-95.

Cobbold, Thomas. "List of Entozoa from Animals Dying at the Society's Menagerie between the Years 1857-60." Proceedings of the Zoological Society of London (1861): 117-27.

Coleman, William and Frederick Lawrence (eds). The Investigative Enterprise: Experimental Physiology in Nineteenth-century Medicine. Berkeley: University of California Press, 1988.

Cowie, Helen. Exhibiting Animals in Nineteenth-Century Britain: Empathy, Education, Entertainment. Basingstoke: Palgrave Macmillan, 2014.

Cox, J.C. "On Atmospheric Causes as Influencing the Health of Exotic Animals Kept in Confinement in England." Proceedings of the Zoological Society of London II (1832): 33-8.

Cox, J.C. Hints for Invalids about to Visit Naples Being a Sketch of the Medical Topography of that City. London: Longman \& Company, 1841.

Crisp, Edwards. A Treatise on the Structure and Use of the Spleen. London: The author, 1855.

Crisp, Edwards. "On the Causes of Death of the Animals in the Society's Gardens from 1851 to 1860." Proceedings of the Zoological Society of London (1860): 175-83.

Cunningham, Andrew. The Anatomist Anatomis'd: An Experimental Discipline in Enlightenment Europe. Ashgate: Farnham, 2010.

Darwin, Charles. The Variation of Animals and Plants under Domestication, Vol. II. London: John Murray, 1868.

Darwin, Frank and A.H. Garrod. "Notes on an Ostrich Lately Living in the Society's Collection." Proceedings of the Zoological Society of London (1872): 356-63. 
de Courcy, Catherine. “Zoology: Trevelyan's Rhinoceros and other Gifts from India to Dublin Zoo." History Ireland 18 (2010). Accessed February 16, 2017. http://www.historyireland.com/eighteenth-nineteenth-century-history/zoologytrevelyans-rhinoceros-and-other-gifts-from-india-to-dublin$\mathrm{zOO} /$.

de Courcy, Catherine. Dublin Zoo: An Illustrated History. Cork: Collins Press, 2009.

Desmond, Adrian. "The Making of Institutional Zoology in London, 1822-36." History of Science 23 (1985): 153-85, 223-50.

Desmond, Adrian. The Politics of Evolution. London: University of Chicago Press, 1989.

Desmond, Adrian. "Redefining the X Axis: 'Professionals,' 'Amateurs' and the Making of Mid-Victorian Biology-A Progress Report." Journal of the History of Biology 34 (2001): 3-50.

Dick, H. "Two Italian Greyhounds Suffering from Rickets." Transactions of the Pathological Society of London 14 (1863): 289-90.

Dobson, Jessie. "Dr. Edwards Crisp: A Forgotten Medical Scientist.” Journal of the History of Medicine and Allied Sciences 7 (1952): 384-400.

Editorial. "On Phthisis in Monkeys and Other Animals." Lancet 22 (1834): 145-7.

Erichsen, Mr. "Introductory Address.” British Medical Journal 2 (1873): 413.

Eyler, John. Victorian Social Medicine: The Ideas and Methods of William Farr. London: John Hopkins University Press, 1979.

Flack, A.J.P. "Science, 'Stars' and Sustenance: The Acquisition and Display of Animals at the Bristol Zoological Gardens, 1836-c.1970." In Wild Things: Nature and the Social Imagination, edited by W.I. Beinart, S. Pooley and K. Middleton, 163-84. Cambridge: White Horse Press, 2013.

Flack, A.J.P. “The Natures of the Beasts: An Animal History of Bristol Zoo since 1835," (PhD diss., University of Bristol, 2014).

Flower, W.H. “Correspondence.” May 27, 1881. Council and General Minute Books, Royal Society of Medicine Archive: PSL/A/4.

Flower, Professor. "Address to the General Meeting." Zoological Society of London. Annual Report (1887): 55-67.

Foster, W.D. "Thomas Spencer Cobbold and British Parasitology." Medical History 5 (1961): 341-8.

Foucault, M. The Birth of the Clinic. London: Tavistock, 1973.

Furman, I.B. "The History of Zoos and the Emergence of Zoo Veterinarians." Veterinary Heritage 19 (1996): 20-3.

Garrod, A. Evidence to United Kingdom Parliament. Royal Commission on the Practice of Subjecting Live Animals to Experiments for Scientific Purposes. Minutes of Evidence, Vol. XLI, C.1391-1. London: The Stationary Office, 1876: 107. 
Goffman, Ernest. Asylums. Essays on the Social Situation of Mental Patients and Other Inmates. Harmondsworth: Penguin, 1968.

Granshaw, L. "'Upon this Principle I have Based a Practice:' The Development and Reception of Antisepsis in Britain, 1867-90." In Medical Innovations in Historical Perspective, edited by John Pickstone, 17-46. Basingstoke: Palgrave Macmillan, 1992.

Green-Armytage, A.H.N. The Story of Bristol Zoo. Bristol: Bristol, Clifton \& West of England Zoological Society, 1964.

Hamlin, C. "Edwin Chadwick, 'Mutton Medicine,' and the Fever Question." Bulletin of the History of Medicine 70 (1996): 233-65.

Hamlin, C. Public Health and Social Justice in the Age of Chadwick: Britain, 1800-1854. Cambridge: Cambridge University Press, 1998.

Hancocks, David. A Different Nature: The Paradoxical World of Zoos and their Uncertain Future. Berkeley: University of California Press, 2001.

Hardy, Anne. "Animals, Disease and Man: Making Connections." Perspectives in Biology and Medicine 46 (2003a): 200-15.

Hardy, Anne. "Commentary: Bread and Alum, Syphilis and Sunlight: Rickets in the Nineteenth Century." International Journal of Epidemiology 32 (2003b): $337-40$.

Harrison, Robert. "An Account of Tubercles in the Air-Cells of a Bird, and Some Observations on Tubercles in General." The Dublin Journal of Medical Science 11 (1837): 226-36.

Haughton, Samuel. "Notes on Animal Mechanics: No. 16. On the Muscular Anatomy of the Rhinoceros." Proceedings of the Royal Irish Academy 9 (186466): $515-24$.

Haughton, Samuel. Principles of Animal Mechanics. Dublin: 1873.

Hochadel, Oliver. "Science in the Nineteenth Century Zoo." Endeavour 29 (2005): 38-42.

Hochadel, Oliver. "Watching Exotic Animals Next Door: 'Scientific' Observations at the Zoo (ca. 1870-1910)." Science in Context 24 (2011): 183-214.

Houston, Dr. "On the Diseases of the Animals which Died in the Collection." Dublin Journal of Medical and Chemical Science 5 (1834): 285-88.

Humphry, George Murray. "A Course of Lectures on Surgery." Provincial Medical and Surgical Journal 14 (1850): 141-8.

Hutchinson, Herbert. The Life and Letters of Jonathan Hutchinson. London: Wm. Heinemann-Medical Books, 1946.

Hutchinson, Jonathan. "Notes on the Advance of Physic: Being the Annual Oration Before the Hunterian Society, 1864-5." British Medical Journal 1 (1865): 296.

Hutchinson, Woods. "Darwinism and Disease." Journal of the American Medical Association xix (1892): 147-51. 
Ito, Takashi. London Zoo and the Victorians, 1828-1859. London: Royal Historical Society, 2014.

Jackson Clarke, J. Descriptive Catalogue of the Pathological Museum of St. Mary's Hospital. London: Morton and Burt, 1891.

Jacyna, L.S. "Principles of General Physiology: The Comparative Dimension to British Neuro-science in the 1830s and 1840s." Studies in the History of Biology 7 (1984a): 47-92.

Jacyna, L.S. "The Romantic Programme and the Reception of Cell Theory in Britain." Journal of the History of Biology 17 (1984b): 13-48.

Jennison, George. The Making and Growth of the Famous Zoological Gardens, Belle Vue, Manchester. Disley: Berwick Lodge, 1929.

Jessop, W.J.E. "Samuel Haughton: A Victorian Polymath." Hermathena 116 (1973): 3-26.

Jewson, N. "The Disappearance of the Sick-Man from Medical Cosmology, 1770-1870." Sociology 10 (1976): 225-44.

Jones, D.M. "The Maintenance of Animal Health in the Collections." In The Zoological Society of London 1826-1976 and Beyond, edited by Professor Lord Zuckerman, 204-14. London: Academic Press, 1976.

Keeling, C. "Zoological Gardens of Great Britain.” In Zoo \& Aquarium History, edited by V.N. Kisling, 49-74. Boca Raton: CRC Press, 2001.

Keith, A. Illustrated Guide to the Museum of the Royal College of Surgeons, England. London: Royal College of Surgeons, 1910.

Lauder Lindsay, W. "The Artificial Production of Human Diseases in the Lower Animals." Lancet 111 (1878): 380-81, 417, 490, 564.

Li, Shang-Jen. "Natural History of Parasitic Disease: Patrick Manson's Philosophical Method." Isis 93 (2002): 206-28.

Logan, Cheryl. "Before There Were Standards: The Role of Test Animals in the Production of Empirical Generality in Physiology." Journal of the History of Biology 35 (2002): 329-63.

"Medical Societies: The Pathological Society of London." British Medical Journal 2 (1882): 1308.

Medical Superintendent. "Journal." 1838-41. Archives of the Zoological Society of London: GB 0814 RAAB.

Miller, Ian. Nature of the Beasts: Empire and Exhibition at Tokyo Imperial Zoo. Berkeley: University of California Press, 2013.

Murie, James. "Yearly Report for 1866." In Prosector's Report (1865-8). Archives of the Zoological Society of London: GB 0814 RAAC.

Murie, James. "The Cause of Death of the Sea Bear Lately Living in the Society's Gardens." Proceedings of the Zoological Society of London (1867): 243-4.

Murie, James. "On the Morbid Appearances Observed in the Walrus Lately Living in the Society's Gardens." Proceedings of the Zoological Society of London (1868): 67-71. 
Murie, James. "On a Case of Variation in the Horns of a Panolian Deer." Proceedings of the Zoological Society of London (1870): 611-5.

Nance, Susan. Animal Modernity: Jumbo the Elephant and the Human Dilemma. Basingstoke: Palgrave Macmillan, 2015.

"Novel Operation." Blackburn Standard, June 24, 1835: 2.

Nyhart, Lynn. Biology Takes Form: Animal Morphology and the German Universities, 1800-1900. Chicago: University of Chicago Press, 1995.

Nyhart, Lynn. Modern Nature: The Rise of the Biological Perspective in Germany. London: University of Chicago Press, 2009.

“Obituary: Sir John Sibbald." British Medical Journal 1 (1905): 1019-20.

Pagel, Walter. "The Speculative Basis of Modern Pathology: Jahn, Virchow, and the Philosophy of Pathology." Bulletin of the History of Medicine 18 (1945): $1-41$.

"Pathological Society of London." British Medical Journal 1 (1879): 123-5.

"Pathological Society of London." Lancet 119 (1882): 27.

"Pathological Society of London." The Lancet 122 (1883): 685-6.

"Pathological Society of London." The Lancet 129 (1887): 268.

"Pathological Society of London: Annual General Meeting." January 1, 1879. Minute book 3, Royal Society of Medicine Archive, London: PSL/A/3.

"Pathological Society of London: Sub-committee Meeting." March 28, 1881. Council and General Minute Books, Royal Society of Medicine Archive, London: PSL/A/4.

"Pathological Society of London: Council Meeting." October 18, 1881. Council and General Minute Books, Royal Society of Medicine Archive, London: $\mathrm{PSL} / \mathrm{A} / 4$.

Power, W.H. "Thoughts on the Nature of Certain Observed Relations between Diphtheria and Milk." Transactions of the Pathological Society London 30 (1879): 546-51.

"Proceedings of the Pathological Society of Dublin." The Dublin Quarterly Journal of Medical Science 40 (1865): 201.

Proceedings of the Royal Zoological Society of Ireland.

"Prosector's Report." 1865-68. Archives of the Zoological Society of London: GB 0814 RAAC.

"Prosectorial Committee: Meetings." 1869-70. Archives of the Zoological Society of London: GB 0814 RBA.

Ritvo, Harriet. The Animal Estate. Cambridge: Harvard University Press, 1987.

Rothfels, Nigel. Savages and Beasts: The Birth of the Modern Zoo. London: John Hopkins University Press, 2002.

"Royal Zoological Gardens-Management of a Sick Leopard." Freeman's Journal and Daily Commercial Advertiser, June 12, 1840: n.p.

"Scientific Intelligence." The Dublin Journal of Medical Science 23 (1843): 207-10.

Sclater, P. “The Zoological Gardens.” Morning Post, February 7, 1861: 5. 
Simon, John. “A Course of Lectures in General Pathology.” Lancet 56 (1850): 138.

"Skull, Rickets, Osteomalacia." 1947. Museum Collections, Royal College of Surgeons, London: RCSOM/G 46.12.

Spectator. "To the Editor of The Times." The Times, February 26, 1836: 6.

Spooner, Charles. "Notes of the Post Mortem Examination of a Dromedary." Proceedings of the Zoological Society of London II (1832): 126-7.

Spooner, Charles. "Notes on the Post Mortem Examination of a M'horr Antelope." Proceedings of the Zoological Society of London I (1833): 2-3.

"State Medicine." The Lancet 105 (1875): 774-5.

"Surgeon's Journal." 1829-31. Archives of the Zoological Society of London: GB 0814 RAAA.

"The Pathology of Rickets." Transactions of the Pathological Society of London 32 (1881): 313-91.

Vernon, James. Hunger: A Modern History. London: Belknap, 2007.

Virchow, Rudolph. Cellular Pathology. Translated by Frank Chance. London: 1860 .

Wilkinson, Lise. Animals and Disease: An Introduction to the History of Comparative Medicine. Cambridge: Cambridge University Press, 1992.

Williams, W. Roger. The Principles of Cancer and Tumour Formation. London: John Bale \& Sons, 1888.

Wiltshire, Alfred. "Lectures on the Comparative Physiology of Menstruation." British Medical Journal I (1883): 446-8, 500-2.

Wiltshire, Alfred. "Lectures on the Comparative Physiology of Menstruation." British Medical Journal I (1884): 301-5.

Woods, Abigail and Stephen Matthews. "Little, If At All, Removed from the Illiterate Farrier or Cow-Leech': The English Veterinary Surgeon, c.186085, and the Campaign for Veterinary Reform.” Medical History 54 (2010): 29-54.

Woods, Abigail. "From One medicine to Two: The Evolving Relationship between Human and Veterinary Medicine in England, 1791-1835." Bulletin of the History of Medicine 91 (2017): 494-523.

Worboys, Michael. Spreading Germs: Disease Theories and Medical Practice in Britain, 1865-1900. Cambridge: Cambridge University Press, 2000.

Youatt, William. "Illustrations of Disease." Veterinarian vii (1834): 428.

Youatt, William. "Contributions to Comparative Pathology no. 1: Inflammation of the Joints-Moose Deer." Veterinarian ix (1836a): 23-7.

Youatt, William. "Contributions to Comparative Pathology no. 2: EnteritisRhinocerous." Veterinarian ix (1836b): 85-8.

Youatt, William. "Phthisis: Lioness." Veterinarian ix (1836c): 89-93.

Youatt, William. "Account of the Habits and Illness of the Late Chimpanzee." The Lancet 26 (1836d): 202-6. 
Youatt, William. "Contributions to Comparative Pathology no. 5: Intestinal Fever and Ulceration in a Chimp." Veterinarian ix (1836e): 271-82.

Zampieri, Fabio. "Medicine, Evolution, and Natural Selection: An Historical Overview." The Quarterly Review of Biology 84 (2009): 333-55.

"Zoological Society of London, Meeting of Council." 1829-33. Archives of the Zoological Society of London: GB 0814 FAA.

Zoological Society of London. Annual Report.

Open Access This chapter is licensed under the terms of the Creative Commons Attribution 4.0 International License (http://creativecommons. org/licenses/by/4.0/), which permits use, sharing, adaptation, distribution and reproduction in any medium or format, as long as you give appropriate credit to the original author(s) and the source, provide a link to the Creative Commons license and indicate if changes were made.

The images or other third party material in this chapter are included in the chapter's Creative Commons license, unless indicated otherwise in a credit line to the material. If material is not included in the chapter's Creative Commons license and your intended use is not permitted by statutory regulation or exceeds the permitted use, you will need to obtain permission directly from the copyright holder.

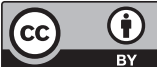

